\title{
Estimation of $\mathrm{NO}_{\mathrm{x}}$ Emissions From Pulverized Coal-Fired Utility Boilers CRADA PC94-005, Final Report
}

May 1995

David J. Wildman
Scott M. Smouse
RECEIVED

ELD 251998

OSTI

\author{
U.S. Department of Energy \\ Pittsburgh Energy Technology Center \\ 626 Cochrans Mills Road \\ Pittsburgh, PA 15236 \\ and \\ Electric Power Research Institute \\ 3412 Hillview Avenue \\ P.O. Box 10412 \\ Palo Alto, CA 94303-1395
}

DISCLAIMER

\begin{abstract}
This report was prepared as an account of work sponsored by an agency of the United States Government. Neither the United States Government nor any agency thereof, nor any of their employees, makes any warranty, express or implied, or assumes any legal liability or responsibility for the accuracy, completeness, or usefulness of any information, apparatus, product, or process disclosed, or represents that its use would not infringe privately owned rights. Reference herein to any specific commercial product, process, or service by trade name, trademark, manufacturer, or otherwise does not necessarily constitute or imply its endorsement, recommendation, or favoring by the United States Government or any agency thereof. The views and opinions of authors expressed herein do not necessarily state or reflect those of the United States Government or any agency thereof.
\end{abstract}




\section{DISCLAIMER}

Portions of this document may be illegible electronic image products. Images are produced from the best available original document. 


\title{
ESTIMATION OF NO $\mathrm{O}_{\mathrm{x}}$ EMISSIONS FROM PULVERIZED COAL-FIRED UTILITY BOILERS
}

\author{
David J. Wildman \\ Scott M. Smouse \\ United states Department of Energy \\ Pittsburgh Energy Technology Center \\ Pittsburgh, PA 15236-0940
}

\begin{abstract}
The formation of nitrogen oxides $\left(\mathrm{NO}_{\mathrm{x}}\right)$ during pulverized-coal combustion in utility boilers is governed by many factors, including the boiler's design characteristics and operating conditions, and coal properties. Presently, no simple, reliable method is publicly available to estimate $\mathrm{NO}_{x}$ emissions from any coal-fired boiler. A neural network back-propagation algorithm was previously developed using a small data set of boiler design characteristics and operating conditions, and coal properties for tangentially fired boilers. This initial effort yielded sufficient confidence in the use of neural network data analysis techniques to expand the data base to other boiler firing modes. A new neural network-based algorithm has been developed for all major pulverized coal-firing modes (wall, opposed-wall, cell, and tangential) that accurately predicts $\mathrm{NO}_{x}$ emissions using 11 readily available data inputs. A sensitivity study, which was completed for all major input parameters, yielded results that agree with conventional wisdom and practical experience. This new algorithm is being used by others, including the Electric Power Research Institute (EPRI). EPRI has included the algorithm in its new software for making emissions compliance decisions, the Clean Air Technology Workstation.
\end{abstract}

\section{Introduction}

The formation of nitrogen oxides $\left(\mathrm{NO}_{x}\right)$ during pulverized-coal combustion in utility boilers is governed by many factors, including the boiler's design characteristics and operating conditions, and coal properties. Presently, no simple, reliable method is publicly available to estimate $\mathrm{NO}_{x}$ emissions from any coal-fired boiler. The authors previously showed that existing empirical methods were inadequate for predicting $\mathrm{NO}_{x}$ emissions from even a small data set of tangentially fired utility boilers (1). To provide a simple, short-term, multi-purpose means to predict $\mathrm{NO}_{x}$ emissions from pulverized coal-fired utility boilers, a neural network backpropagation algorithm was previously applied to a data set for nine tangentially fired boilers (1). The purpose of this initial study was to assess the ability of a 
neural network to reasonably predict $\mathrm{NO}_{x}$ emissions for a qualified data set. As previously reported (1), the algorithm developed by the Pittsburgh Energy Technology Center (PETC) generally predicted $\mathrm{NO}_{\mathrm{x}}$ emissions to within $\pm 50 \mathrm{ppm}$ of actual values for the tangentially fired boilers in the limited initial data set.

The Electric Power Research Institute (EPRI) is developing a variety of software tools to assist its member utilities with making decisions on how to comply with the Clean Air Act Amendments of 1990 and the changing power generation marketplace. Sargent \& Lundy Engineers has developed the Clean Air Technology (CAT) Workstation as the primary compliance decision tool for EPRI's member utilities. The CAT Workstation includes modules to comparatively evaluate various emissions control technologies. After the 1993 Joint Symposium on Stationary Combustion $\mathrm{NO}_{x}$ Control, where the previous work was presented, EPRI expressed an interest in using PETC's neural network-based algorithm within the CAT Workstation. However, because the data base upon which the initial algorithm was developed was limited to tangentially fired boilers, PETC recommended collection of additional data and development of a new $\mathrm{NO}_{x}$ algorithm.

Subsequently, a Cooperative Research and Development Agreement (CRADA) was implemented between PETC and EPRI to collect additional power plant data, develop a new algorithm, and provide a copy of the coded algorithm to Sargent \& Lundy for inclusion in the CAT Workstation. This effort was initiated in early 1994 and concluded by mid-year 1994 to meet the deadline for release of the CAT Workstation to EPRI's member utilities.

Technology-based standards, such as Reasonably Available Control Technology (RACT), that require the installation of $\mathrm{NO}_{x}$ control technologies on a boiler-byboiler basis are driving the emissions compliance strategies of U.S. utilities. Carnegie Mellon University's (CMU) Department of Engineering and Public Policy is examining the potential cost savings achievable through $\mathrm{NO}_{\mathrm{x}}$ emissions trading, an alternative market-based strategy to achieve federal and state goals for $\mathrm{NO}_{\mathrm{x}}$ emission reduction (2). To estimate the potential cost savings achievable through inter-utility $\mathrm{NO}_{x}$ trading, $\mathrm{CMU}$ is using a combinatorial optimization approach to identify boiler retrofits and operating parameters that yield the most cost-effective means for $\mathrm{NO}_{x}$ abatement (2). PETC's new neural network-based algorithm for predicting $\mathrm{NO}_{x}$ emissions was utilized by $\mathrm{CMU}$ to predict emissions from pulverized coal-fired boilers in the Pittsburgh, Pennsylvania, area as part of its efforts. CMU is continuing the development of its trading analysis software for $\mathrm{NO}_{\mathrm{x}}$ emissions using PETC's algorithm to predict $\mathrm{NO}_{\mathrm{x}}$ emissions.

This paper summarizes the development of the new neural network-based algorithm, including a review of the data base used in the effort and a sensitivity study for the major input parameters. Planned efforts to significantly expand the existing data base using data and information being collected by the U.S. Environmental Protection Agency (EPA) from U.S. utilities, as required by the Clean Air Act Amendments of 1990, is briefly discussed. 


\section{Neural Network Approach for Estimating $\mathrm{NO}_{x}$ Emissions}

Neural networks became popular in the 1980 s for analyzing complex, interrelated data sets. Neural networks do not assume that a relationship is known between process input and output but rather try to determine the relationship by analyzing data sets of input and output data. Neural networks, which can be viewed as a nonlinear data analysis technique, are computational systems that use the organizational principles of biological nervous systems. Computer scientists imitate these principles because biological systems easily outperform all current approaches for pattern recognition. The primary requirement for developing a neural network is a complete data set. Also, the proper representation of the input (e.g., a ratio of two variables may be the best representation) hastens the training process.

Neural networks consist of several simple, highly interconnected data-processing units. These units approximate the complex system of neurons and electrochemical signals used by the human brain to process information (3). Each of the neurons in the human brain functions like a tiny computer with limited capabilities. Connected together, these cells form the most intelligent system known. Neural networks are a relatively new class of computing systems formed from hundreds of simulated neurons interconnected like the brain's neurons. The principal aim of the technology is to mimic nature's approach for processing data and information. The back-propagation algorithm developed independently by at least three groups (4-6) is the most widely used neural network approach.

Neural networks are being used to solve real problems. For example, they have been shown to be effective in estimating the fatigue life of mechanical parts (7), performing fault detection in chernical plants (8), diagnosing automobile malfunctions (9), and recognizing human speech (10). Neural networks are also being widely applied within the power industry (3). During the last five years, more than 200 technical papers discussing artificial intelligence applications in the power industry have been published; more than one-half of these applications involved the back-propagation algorithm (11). All of the above applications used noisy data, where the relationships between input-output pairs were complicated and poorly understood. Neural networks generally excel over traditional data analysis techniques, such as multiple linear regression techniques, in analyzing noisy data sets.

Commercial neural network software, Brainmaker Professional (Version 2.03) from California Scientific Software, was used in this study. During the network development process, the user defines the problem and collects the input-output pairs. If the user neglects key input parameters for a particular application, the predictive capabilities of the network will suffer. A neural network is not programmed with rules like an expert system, but rather it "learns" in much the same way that people do, i.e., by example and repetition. 
After the input-output pairs are collected, the learning stage commences with the network associating output data with input data. Each time an input is presented, the network sends back an answer of what it thinks the output should be. When it is wrong, the network corrects itself by changing the weight matrices that are used to adjust the input-output relationships. Brainmaker Professional uses a backpropagation algorithm to adjust these weight matrices. The training process is repeated until the network derives answers that are within a user-specified tolerance for all inputs. This learning process can take considerable time, possibly up to several days or weeks, to complete depending on the complexity of the problem and the processing speed of the computer used. The final weight matrices are saved to file and can be used external to Brainmaker Professional to predict outputs for other sets of input parameters.

Key to the training process in a neural network is the transfer function. Output is determined by the network's nodes, which combine signals sent to them by lowerlayered nodes and transfer these adjusted signals to higher-layered nodes. Neural network nodes are designed to process signals with values between 0 and 1 ; therefore, all input variables must be scaled to the unit interval. Nonlinear transfer functions send signals from node to node within the network. The default transfer function used by Brainmaker Professional is the sigmoid function:

$$
f(x)=\frac{1}{1+\exp (-x)}
$$

Figure 1 shows that the sigmoid function maps real numbers into the unit interval. It is often called a "squashing function" because very large positive values are asymptotically mapped to 1 and very large negative values are asymptotically mapped to zero. The squashing function forces the network to focus on the bulk of the data and to place less emphasis on the data at the extreme lower and upper ends of a data set. Hence, network predictions are generally less accurate at the data extremes.

A network stops training when its answers are within a user-specified tolerance. This tolerance specification is applied to the data after it has been subjected to the squashing function. The nonlinear nature of the squashing function often causes extreme data values to deviate more from actual values than nonextreme data. Typically, training is conducted at progressively smaller tolerance levels until the deviation between predicted and actual values is acceptable by the user. The value of acceptable deviation between the network answers and the actual data depends upon the accuracy of the available input-output pairs. For example, if inherent errors in the available input-output pairs limit their repeatability to $5 \%$, then training to a tolerance less than 0.1 is unwise. Although decreasing the tolerance will force the network answers to more closely approximate the training data, the network will not necessarily perform better on new data sets. Usually, continued training at progressively smaller tolerances improves the network's 
performance to a point beyond which it deteriorates. Once confidence is obtained in the predictive capabilities of the neural network, it is used to generate answers for input sets with unknown outputs.

\section{Definition and Scope of Study}

To expand the initial data base, additional data were collected from a variety of sources, including several electric utilities, the Utility Air Regulatory Group (UARG), and several projects within USDOE's Clean Coal Technology Program. A total of 384 data sets from 36 pulverized coal-fired boilers were collected and used in this study. Thousands of other data sets were also collected but were not usable because they lacked key data inputs. Also, some data were collected from cyclone-fired utility boilers but were not analyzed because this effort was limited to pulverized coal-fired boilers. Multiple data sets were available for some boilers because of variations in operating conditions and coal type. Some boilers had emissions data from burners originally installed when the unit was built. They were either conventional or low- $\mathrm{NO}_{x}$ burners, and low- $\mathrm{NO}_{x}$ burners retrofitted at a later date. Both pre- and post-NSPS (New Source Performance Standards) boilers were included in the data set. Table 1 summarizes the characteristics of the boilers in the available data set as a function of firing mode le.g., wall, opposedwall, cell, tangentiall. No data were available from wall-fired units with low- $\mathrm{NO}_{\mathrm{x}}$ burners, largely as a result of the limited time available to produce an algorithm for inclusion in EPRI's CAT Workstation. The new tangentially fired boiler data consisted of a few data sets from many boilers whereas the data for the other boiler types consisted of many data sets from a few boilers. The capacity ranges of the wall-fired boilers, opposed wall-fired boilers, and cell burner-equipped boilers were limited compared to that of the tangentially fired boilers because attempts to acquire additional data over a broader capacity range were unsuccessful during the limited available time.

A number of possible input parameters, based on boiler design characteristics and operating conditions, and fuel properties, were considered during development of the new $\mathrm{NO}_{x}$ algorithm. The objective was to use a limited number of simple, readily available parameters as long as the predicted $\mathrm{NO}_{\mathrm{x}}$ values agreed reasonably with actual emission values for a range of boiler types, boiler operating conditions, and coal properties. The starting point for selection of the new input parameters was the list of parameters used for the original $\mathrm{NO}_{x}$ algorithm. However, data availability precluded use of some of the original inputs and extension of the data set to additional boiler types required inclusion of new parameters to adequately describe the various boiler designs.

Table 2 summarizes the parameters that were eventually selected as input to the new neural network. Furnace height, which is used to calculate the furnace volumetric heat release rate, was defined in this effort as the distance from the bottom of the ash hopper to the furnace roof (i.e., the overall boiler height). The 
more standard definition for boiler height, which is the distance from the furnace hopper knuckle to the furnace nose, was not used because detailed furnace dimensions were not available for all units and time limitations did not permit collection of this data from individual power stations. The year that the boiler first became operational was used because recent boiler designs attempt to limit $\mathrm{NO}_{\mathrm{x}}$ formation in conjunction with low- $\mathrm{NO}_{\mathrm{x}}$ burners. The year that the current burners were installed was used as an indicator of the developmental status or maturity of low-NO $\mathrm{N}_{x}$ burner technology. It would be too difficult to use individual burner design specifications for different manufacturers in this simplistic approach. The ratio of boiler load to the boiler's maximum continuous rating (MCR), along with the plan area and volumetric heat release rates, are used to reflect a boiler's overall design and operating characteristics. Most utilities provided the $\mathrm{NO}_{x}$ and excess oxygen values at the economizer outlet; therefore, this emissions sampling location was selected. Other utilities provided $\mathrm{NO}_{x}$ and $\mathrm{O}_{2}$ data at the boiler exit or stack. However, there were fewer data sets with this information. Also, because leakage of air into the exhaust system of a plant can not be distinguished from operating conditions with higher excess air, stack emissions data are difficult to use. Therefore, only data sets with the oxygen content in flue gas at the economizer outlet were used in this study. No input parameter was used to address the impact of over-fire air usage or mill firing pattern on $\mathrm{NO}_{x}$ emissions because sufficient data were not available for network training. While omission of these parameters is recognized as a significant weakness because they are known to have a major impact on $\mathrm{NO}_{x}$ emissions levels, the previous effort yielded reasonable $\mathrm{NO}_{x}$ emissions estimates for a wide variety of boilers, boiler operating conditions, and coal types without inclusion of this information.

\section{Neural Network Results}

Figure 2 compares the actual and estimated $\mathrm{NO}_{\mathrm{x}}$ emission values for the 346 data sets used to train the network. The network was trained at a tolerance of 0.10 , i.e., training was complete when all of the scaled predicted values (i.e., from the squashing function) agreed to within $10 \%$ of scaled actual values. As previously stated, the nonlinear nature of the sigmoid function causes large deviations between actual and estimated values at the extremes of the data. The greatest difference between an actual $\mathrm{NO}_{\mathrm{x}}$ value and its corresponding estimated value is $263 \mathrm{ppm}$, which occurred for a measured $\mathrm{NO}_{x}$ value of $1350 \mathrm{ppm} 10 \% \mathrm{O}_{2}$, dry volume basis). The standard error of estimate for the training data was $67 \mathrm{ppm}$. Training at a smaller tolerance reduced the maximum deviation and the standard error of estimate but the network performance degraded on the data that was reserved for testing. As shown in Figure 2, the neural network's maximum estimate is $1150 \mathrm{ppm}\left(0 \% \mathrm{O}_{2}\right.$ dry volume basis). Increasing this value would improve the fit for extremely high $\mathrm{NO}_{x}$ emission values but would degrade the fit of the nonextreme data. It was felt that minimizing the deviations between actual and estimated $\mathrm{NO}_{x}$ emissions for the bulk of the (i.e., nonextreme) data was more important than minimizing deviations for the extremely high $\mathrm{NO}_{x}$ emission values. 
The standard error of estimate decreased from $67 \mathrm{ppm}$ to $52 \mathrm{ppm}$ if only the data sets that had an actual $\mathrm{NO}_{x}$ values less than $1150 \mathrm{ppm}\left(0 \% \mathrm{O}_{2}\right.$, dry volume basis) were considered.

Figure 3 compares actual and estimated $\mathrm{NO}_{x}$ emissions for the 38 data sets reserved for testing by the neural network. These data sets represent the balance of data sets in the master data set. The standard error of estimate for the test data was $64 \mathrm{ppm}$. The greatest difference between a measured $\mathrm{NO}_{x}$ value and its corresponding estimated value was $156 \mathrm{ppm}$. This difference was again for a data set with an extremely high actual $\mathrm{NO}_{x}$ emission value.

\section{Sensitivity of Input Variables}

Although the prior study yielded a neural network that was very good at estimating $\mathrm{NO}_{x}$ emission values using readily available input data, little effort was placed on assessing the reasonableness of the data trends predicted using the network algorithm. To assess the sensitivity of the selected input parameters on $\mathrm{NO}_{x}$ emission trends, a series of numerical experiments were performed using the new algorithm. While these experiments do not fully evaluate the accuracy of the algorithm because actual data were not available for comparison in all cases, they do reveal trends that agree with conventional wisdom and practical experience. Also, they demonstrate how the algorithm can be used in various utility scenarios, such as low- $\mathrm{NO}_{x}$ burner retrofits and boiler operational changes. These sensitivity analyses are not meant to describe trends that are universally applicable to all pulverized coal-fired boilers but rather to show that, while the trends are generally reasonable, specific analyses can yield results that require further explanation. To simplify these analyses, input parameters were varied individually except when fuel analysis effects were being assessed. As detailed in Table 3, four different scenarios were analyzed:

1) a pre-NSPS $200 \mathrm{MW}_{\mathrm{s}}$ wall-fired boiler built in 1955 and equipped with the original burners

2) a pre-NSPS $200 \mathrm{MW}_{\mathrm{s}}$ wall-fired boiler built in 1955 and hypothetically retrofitted with low $\mathrm{NO}_{x}$ burners in 1985

3) a pre-NSPS $180 \mathrm{MW}$, tangentially fired boiler built in 1967 and equipped with the original burners

4) a post-NSPS $250 \mathrm{MW}$, tangentially fired boiler built in 1984 and equipped with the original burners

At 5-year increments from 1975 until 1990, the effect of retrofitting low-NO burners on $\mathrm{NO}_{\mathrm{x}}$ emissions is shown in Figure 4 for the pre-NSPS $200 \mathrm{MW}_{e}$ wallfired boiler built in 1955 and the pre-NSPS $180 \mathrm{MW}_{\mathrm{e}}$ tangentially fired boiler built in 1967. In this figure and all subsequent figures, the two dates in parentheses indicate the year that the unit first commercially operated and the year that the current (i.e., either original or retrofit burners) were installed. In this analysis, it 
was assumed that other boiler improvements were implemented when the burners were retrofitted to reduce the flue gas oxygen content at the economizer exit from $8.4 \%$ to $5.4 \%$ for the wall-fired unit and from $5.5 \%$ to $3.5 \%$ for the tangentially fired unit. No other input parameter was varied. Figure 4 and subsequent figures (where data were available) shows the excellent agreement between actual and predicted $\mathrm{NO}_{x}$ emission values. Retrofitting low-NO burners in 1975 reduced the emissions from the wall-fired unit and the tangentially fired unit by about $28 \%$ and $35 \%$ and in 1990 by about $38 \%$ and $38 \%$, respectively. Interestingly, the same $38 \%$ reduction was predicted for both units when low- $\mathrm{NO}_{x}$ burners were retrofitted in 1990. It is not known whether this level of $\mathrm{NO}_{x}$ reduction represents a limit imposed by the limited available data set; additional sensitivity analyses need to be performed for other units to investigate this issue. However, these trends generally do agree with the observed ability of low-NO $\mathrm{N}_{x}$ burners to reduce emissions. Also, essentially no improvement in the ability of low-NO burners to reduce emissions from the tangentially fired boiler was predicted over the period from 1975 to 1990; other plants may show significantly different results.

One of the simplest, most cost-effective means to control $\mathrm{NO}_{x}$ emissions from pulverized coal-fired utility boilers is reducing the operating excess air level. The effect of excess air level on $\mathrm{NO}_{x}$ emissions from the above four units is shown in Figure 5. In these numerical experiments, the excess air level was varied $2 \%$ higher and lower than the actual reported value at the economizer exit of each boiler. Significant changes in $\mathrm{NO}_{x}$ emissions are predicted as the excess oxygen content is varied for all units except the post-NSPS $250 \mathrm{MW}_{\mathrm{e}}$ tangentially fired unit, which has an actual $\mathrm{NO}_{x}$ emission level of only $270 \mathrm{ppm} 10 \% \mathrm{O}_{2}$, dry volume basis). These trends generally agree with actual experience in these units and other field measurements.

Fuel properties can have a significant impact on $\mathrm{NO}_{x}$ emissions from pulverized-coal combustion. Substantial differences in $\mathrm{NO}_{x}$ emissions have been observed when the coal being fired is changed or blended with other coals. The two coals fired in the pre-NSPS $200 \mathrm{MW}_{\mathrm{e}}$ wall-fired unit and the pre-NSPS $180 \mathrm{MW}_{\mathrm{e}}$ tangentially fired unit were selected for a numerical blending simulation. As shown in Table 3, the coal burned in the wall-fired unit had a fixed carbon-to-volatile matter (FC/VM) ratio of 1.42 and the coal burned in the tangentially fired unit had FC/VM of 1.29. These two coals were numerically blended at ratios of $1 / 3,1 / 1$, and $3 / 1$ to produce simulated coals with compositions between the two actual coals. The effect of FC/NM ratio on $\mathrm{NO}_{x}$ emissions is shown in Figure 6 . Significant changes in $\mathrm{NO}_{x}$ emissions are predicted for the two pre-NSPS units whereas the two units with low- $\mathrm{NO}_{x}$ burners are relatively insensitive to fuel properties. Some low-NO burner manufacturers claim that their burners are not sensitive to some fuel properties, such as FC/VM ration, while others report significant sensitivity. Again, other scenarios may show substantially different results.

Boiler design obviously has a major impact on $\mathrm{NO}_{x}$ emissions. Generally, lower furnace heat release rates will yield lower $\mathrm{NO}_{x}$ emissions as a result of lower flame 
temperatures and changes in burner/furnace aerodynamics. Figure 7 shows the effect of plan area heat release rate on $\mathrm{NO}_{\mathrm{x}}$ emissions. In this analysis, changes in the plan area heat release rate of $\pm 5 \%, \pm 10 \%, \pm 15 \%$, and $\pm 20 \%$ from the actual design point for each boilers were evaluated. Also, the volumetric heat release rate and other input parameters were held constant. Because the volumetric heat release rate was held constant, these analyses reflect a change in boiler design (e.g., to achieve lower plan area heat release rates, a unit will be made wider and/or deeper while the unit height is decreased) not a change in boiler firing rate (i.e., load). In general, the effect of plan area heat release rate was minimal for all four units. This result seems contrary to practical experience but can be partially explained by the fact that a change in boiler design to achieve lower $\mathrm{NO}_{x}$ emissions would likely change more than the plan area heat release rate. This is supported by Figure 8 , which shows a very strong effect of volumetric heat release rate for all units except the post-NSPS $250 \mathrm{MW}_{\mathrm{e}}$ tangentially fired unit. This unit has very low actual $\mathrm{NO}_{x}$ emissions. In this analysis, $\mathrm{NO}_{x}$ emissions were determined for incremental changes in furnace volumetric heat release rate of $5 \%$, $10 \%, 15 \%$, and $20 \%$ higher and lower than the actual design point for each boiler. Because the two input parameters of plan area and volumetric heat release rate are so strongly related, it is possible that only one of these inputs is required to adequately describe the combined impact of firing rate and boiler design on $\mathrm{NO}_{x}$ emissions.

\section{Future Work}

The Clean Air Act Amendments of 1990 require most U.S. coal-fired power plants to install continuous emissions monitoring (CEM) systems and to electronically report the collected data to the U.S. Environmental Protection Agency on a quarterly basis. EPA has collected up to a full year of data from some utilities and several quarters of data from the remaining utilities. PETC has worked with EPA on various $\mathrm{NO}_{x}$ issues, including assessing the performance and cost of various combustion and post-combustion control technologies. Discussions have been held with EPA on acquiring the first year's emissions data from all U.S. coal-fired power plants equipped with CEMs to expand the data base for development of a new $\mathrm{NO}_{x}$ prediction algorithm. While this emissions data base would be unequalled by any other, EPA is not authorized to collect all the related information required to predict $\mathrm{NO}_{\mathrm{x}}$ emissions accurately. For example, EPA is not collecting all the boiler design and coal property data that is used in the current $\mathrm{NO}_{x}$ algorithm. Collection of this data would require an effort that is beyond current resources. However, several options to perform this task are still being considered.

PETC has also discussed similar efforts with EPRI to develop a neural networkbased $\mathrm{NO}_{x}$ algorithm for gas- and oil-fired utility boilers. The Gas Research Institute (GRI) has been using EPRI's CAT Workstation, which includes PETC's NO, algorithm, as part of its market projections for natural utilization in coal-fired boilers 
(12). GRI has expressed an interest in an algorithm to predict $\mathrm{NO}_{\mathrm{x}}$ emissions from coal-fired boilers using natural gas co-firing or reburning.

PETC will continue to expand its current data base with a focus on including more data from power plants that have retrofitted low- $\mathrm{NO}_{x}$ burners. When sufficient data are available, a new neural network-based $\mathrm{NO}_{x}$ algorithm will be developed and supplied to existing and new users. PETC hopes to initiate some of the above activities later this year, which will likely result in an improved algorithm for all coal-fired boiler types.

\section{Summary}

A neural network has been developed to estimate $\mathrm{NO}_{x}$ emissions for wall-fired boilers, opposed wall-fired boilers, cell burner-equipped boilers, and tangentially fired boilers. Eleven simple, readily available parameters were selected as input parameters. The data base used in this effort consisted of boiler design characteristics and operating conditions, and coal property data for 36 pulverized coal-fired utility boilers. Some of these boilers were either originally equipped with low- $\mathrm{NO}_{x}$ burners or had been retrofitted with low-NO ${ }_{x}$ burners. A sensitivity analysis of the selected input parameters yielded trends that agree with conventional wisdom and practical experience. Some of the current and future applications for PETC's neural network-based $\mathrm{NO}_{x}$ algorithm were highlighted; the most notable of the current applications is the algorithm's inclusion in the Electric Power Research Institute's Clean Air Technology Workstation, which is the primary tool for making emissions compliance decisions for its member utilities.

\section{Disclaimer}

Reference herein to any specific commercial product by trade name, trademark, manufacturer, or otherwise does not necessarily constitute or imply its endorsement, recommendation, or favoring by the United States Government or any agency thereof. 


\section{References}

1. Smouse, S.M., Wildman, D.J., Mcllvried, T.S., and Harding, N.S., "Estimation of $\mathrm{NO}_{x}$ Emissions from Pulverized Coal-Fired Utility Boilers," EPRI/EPA 1993

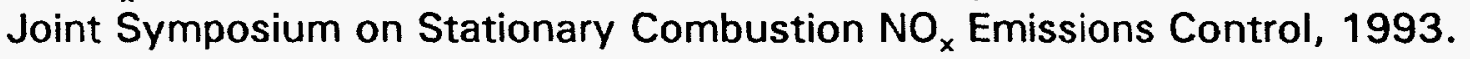

2. Siegel, S.A., and Kalagnanam, J.R., "The Potential Cost Savings of Implementing an Inter-Utility $\mathrm{NO}_{x}$ Trading Program," International Conference on Acid Rain \& Electric Utilities: Permits, Allowances, Monitoring \& Meteorology, Air and Waste Management Association, 1995.

3. Naser, J., "Exploring Neural Network Technology," EPRI Journal, December, 1992.

4. Rumelhart, D.E., Hinton, G., and Williams, R.J., "Learning Internal Representations by Error Propagation" Parallel Distributed Processing, Vol. 1, MIT Press, 1986.

5. Parker, D.B., Optimal Algorithms for Adaptive Networks: Second Order Back Propagation, Second Order Direct Propagation, Second Order Hebbian Learning," Proceedings of IEEE First International Conference on Neural Networks, 1987.

6. Werbos, P.J., "Beyond Regression: New Tools for Prediction and Analysis in Behavior Sciences," PhD Thesis, Harvard University, Cambridge MA, 1974.

7. Troudet, T., and Werrill, W., "A Real Time Neural Net Estimator of Fatigue Life," Proceedings of the International Joint Conference on Neural Networks, 1990.

8. Hoskins, J.C., Kaliyur, K.M., and Himmelblau, D.M., "Incipient Fault Detection and Diagnosis Using Neural Networks," Proceedings of the International Joint Conference on Neural Networks, 1990.

9. Marko, K.A., Feldkamp, L.A., and Puskorius, G.V., "Automotive Diagnostics Using Trainable Classifiers: Statistical Testing and Paradigm Selection," Proceedings of the International Joint Conference on Neural Networks, 1990.

10. Hampshire, J.B., and Waibel, A., "Connectionist Architectures for Multispeaker Phoneme Recognition," Advances in Neural Information Processing Systems 2, 1990.

11. Niebur, D., "Artificial Neural Networks for Power Systems - A Literature Survey," Proceedings of the EPRI Conference on Expert System Applications for the Electric Power Industry, 1993. 
12. Partapas, J., United States Department of Energy Pittsburgh Energy Technology-Gas Research Institute Meeting, Pittsburgh, PA, March, 1995. 
Table 1

Boiler Database Information as a Function of Firing Mode

\begin{tabular}{|c|c|c|c|c|}
\hline $\begin{array}{c}\text { Firing Model } \\
\text { Boiler Information }\end{array}$ & Wall & $\begin{array}{c}\text { Opposed } \\
\text { Wall }\end{array}$ & Cell & Tangential \\
\hline Number of Boilers & 6 & 6 & 3 & 21 \\
\hline $\begin{array}{c}\text { Number of Units } \\
\text { with Low-NO Burners }\end{array}$ & 0 & 3 & 1 & 4 \\
\hline Number of Data Sets & 77 & 96 & 55 & 156 \\
\hline $\begin{array}{c}\text { Number of Units } \\
\text { with 2 Furnaces }\end{array}$ & 1 & 0 & 0 & 9 \\
\hline $\begin{array}{c}\text { Range of Boiler Capacity } \\
\text { (Gross MW })\end{array}$ & $175-200$ & $265-688$ & $610-1300$ & $85-936$ \\
\hline
\end{tabular}


Table 2

Input Parameters Selected for $\mathrm{NO}_{\mathrm{x}}$ Estimation Study

\begin{tabular}{|l|c|c|}
\hline \multicolumn{1}{|c|}{ Parameter } & $\begin{array}{c}\text { Range of } \\
\text { Values }\end{array}$ & Units \\
\hline \hline Plan Area Heat Release Rate & $0.4-3.3$ & $\mathrm{MMBtu}_{\mathrm{ft}}{ }^{2}$ \\
\hline Furnace Volume Heat Release Rate & $3.4-29.7$ & $\mathrm{KBtu} / \mathrm{ft}^{3}$ \\
\hline $\begin{array}{l}\text { Firing Mode } \\
(1=\text { tangential; 2=wall; 3=opposed wall; 4=cell) }\end{array}$ & $1-4$ & - \\
\hline Number of Furnaces & 1 or 2 & - \\
\hline Year Unit First Commercially Operated & $1951-1986$ & year \\
\hline Year Burners Installed (Original or Retrofit Burners) & $1951-1990$ & year \\
\hline Flue Gas Oxygen Content at Economizer Outlet & $1.8-12.1$ & $\begin{array}{c}\text { vol\%, } \\
\text { dry basis }\end{array}$ \\
\hline Load/Maximum Continuous Rating & $0.53-1.12$ & $\mathrm{MW} / \mathrm{MW}$ \\
\hline Coal's Carbon-to-Hydrogen Ratio (C/H) & $13.3-21.3$ & $\mathrm{wt} \% / \mathrm{wt} \%$ \\
\hline Coal's Nitrogen Content & $0.8-1.8$ & $\begin{array}{c}\mathrm{wt} \%, \\
\mathrm{dry} \text { basis }\end{array}$ \\
\hline Coal's Fixed Carbon-to-Volatile Matter Ratio (FC/VM) & $1.0-3.3$ & $\mathrm{wt} \% / \mathrm{wt} \%$ \\
\hline
\end{tabular}


Table 3

Base Input Parameters for Sensitivity Study Cases

\begin{tabular}{|c|c|c|c|c|c|}
\hline Parameter & Units & Unit \#1 & Unit \#2 & Unit \#3 & Unit \#4 \\
\hline Plan Area Heat Release Rate & $\mathrm{MMBtu} / \mathrm{ft}^{2}$ & 1.49 & 1.49 & 1.71 & 1.69 \\
\hline Furnace Volume Heat Release Rate & $\mathrm{KBtu} / \mathrm{ft}^{3}$ & 15.70 & 15.70 & 18.03 & 13.68 \\
\hline $\begin{array}{l}\text { Firing Mode } \\
(1=\text { tangential; } 2=\text { wall; } 3=\text { opposed wall } ; 4=\text { cell })\end{array}$ & - & 2 & 2 & 1 & 1 \\
\hline Number of Furnaces & - & 1 & 1 & 1 & 1 \\
\hline Year Unit First Commercially Operated & year & 1955 & 1955 & 1967 & 1984 \\
\hline Year Burners Installed (Original or Retrofit Burners) & year & 1955 & 1985 & 1967 & 1984 \\
\hline Flue Gas Oxygen Content at Economizer Outlet & $\begin{array}{l}\text { vol\%, } \\
\text { dry basis }\end{array}$ & 8.40 & 5.40 & 5.45 & 2.80 \\
\hline Load/Maximum Continuous Rating & $\mathrm{MW}_{\mathrm{e}} / \mathrm{MW}_{\mathrm{e}}$ & 1.00 & 1.00 & 1.00 & 1.03 \\
\hline Coal's Carbon-to-Hydrogen Ratio $(\mathrm{C} / \mathrm{H})$ & $\mathrm{wt} \% / \mathrm{wt} \%$ & 14.98 & 14.98 & 16.67 & 13.37 \\
\hline Coal's Nitrogen Content & $\begin{array}{l}\text { wt } \%, \\
\text { dry basis }\end{array}$ & 1.70 & 1.70 & 1.49 & 1.09 \\
\hline Coal's Fixed Carbon-to-Volatile Matter Ratio (FC/VM) & $\mathrm{wt} \% / \mathrm{wt} \%$ & 1.42 & 1.42 & 1.29 & 1.02 \\
\hline
\end{tabular}




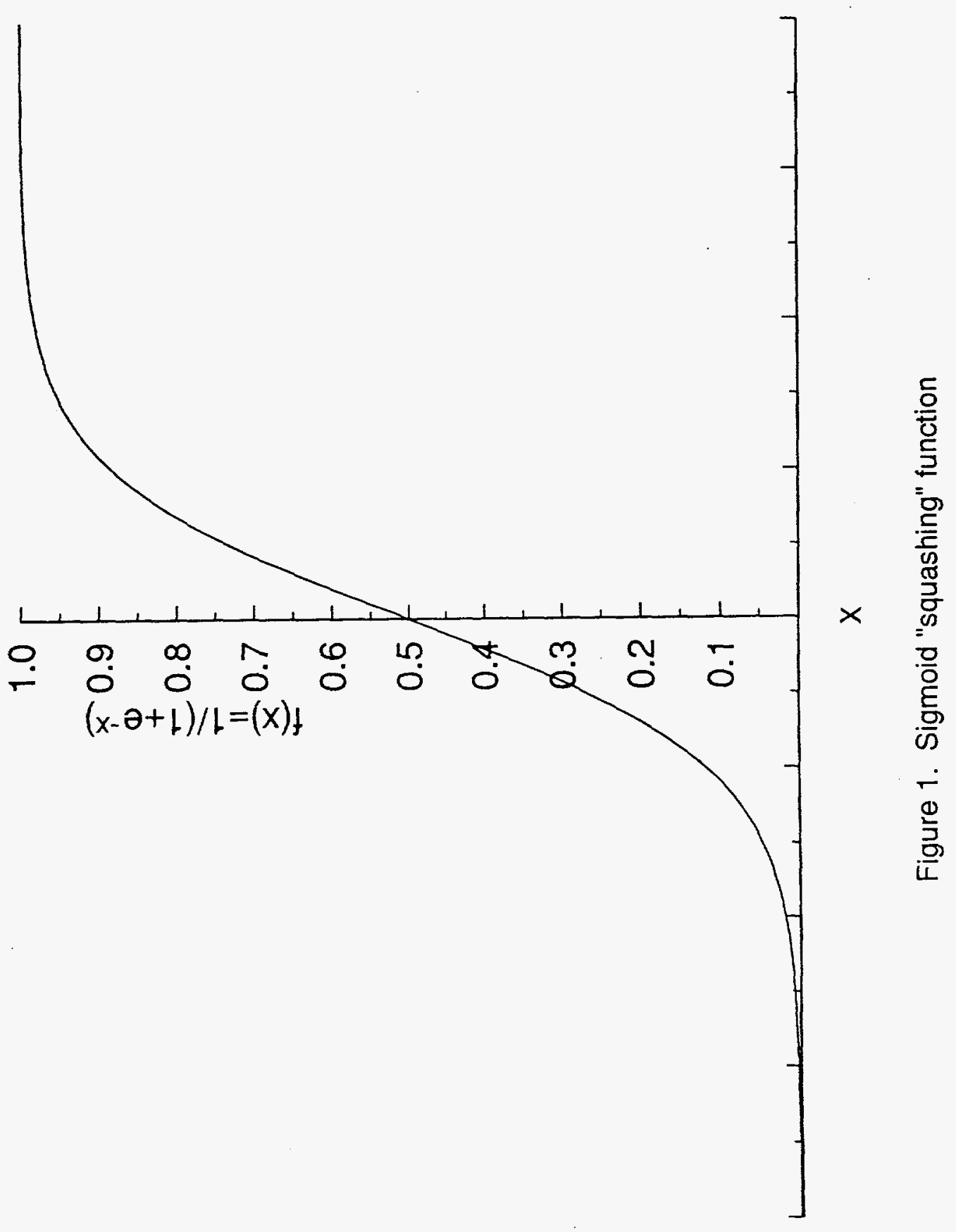




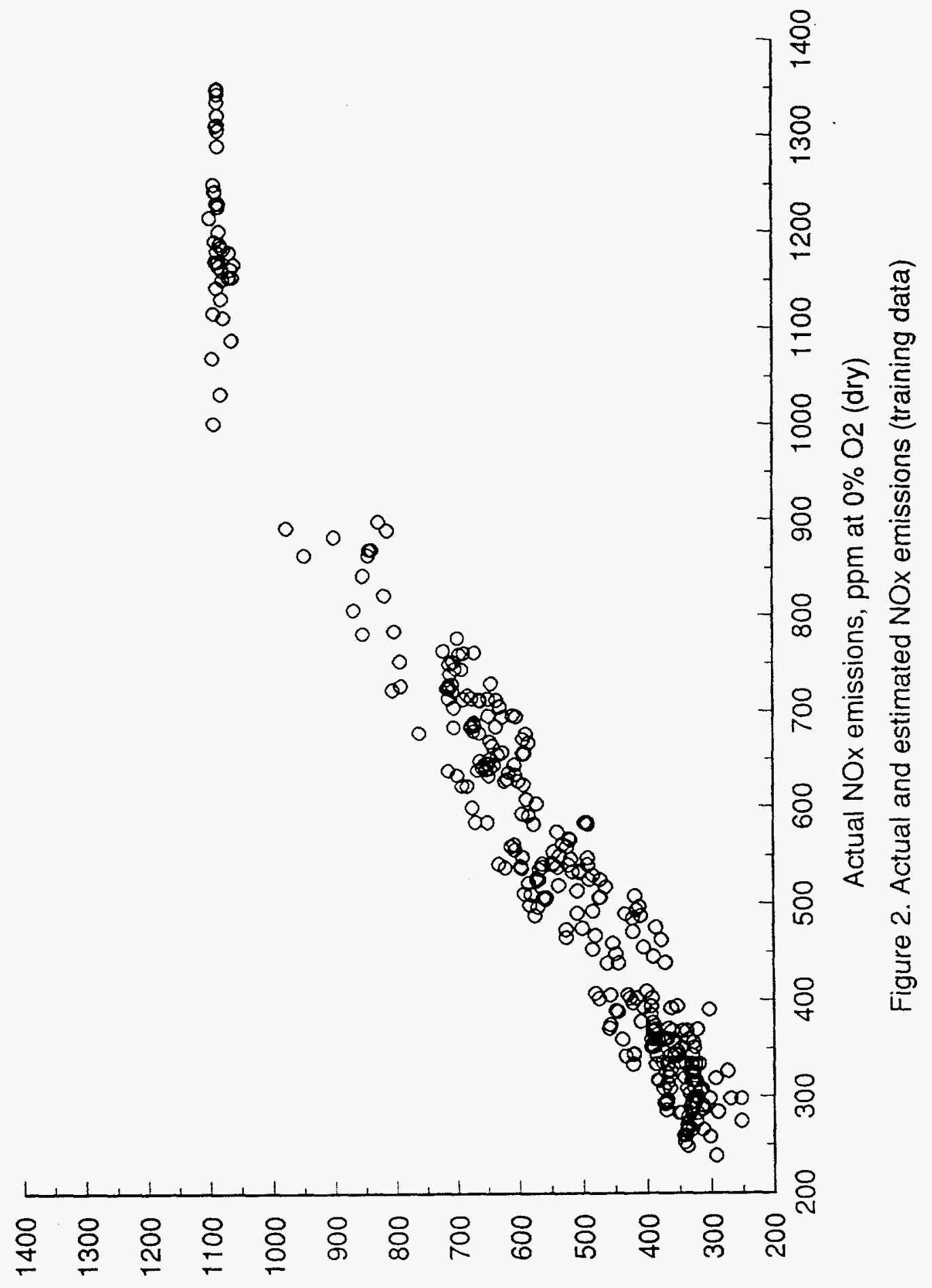

(Kup) $20 \% 0$ le wdd 'suo!ss!ma xON paleu!!s $\exists$ 


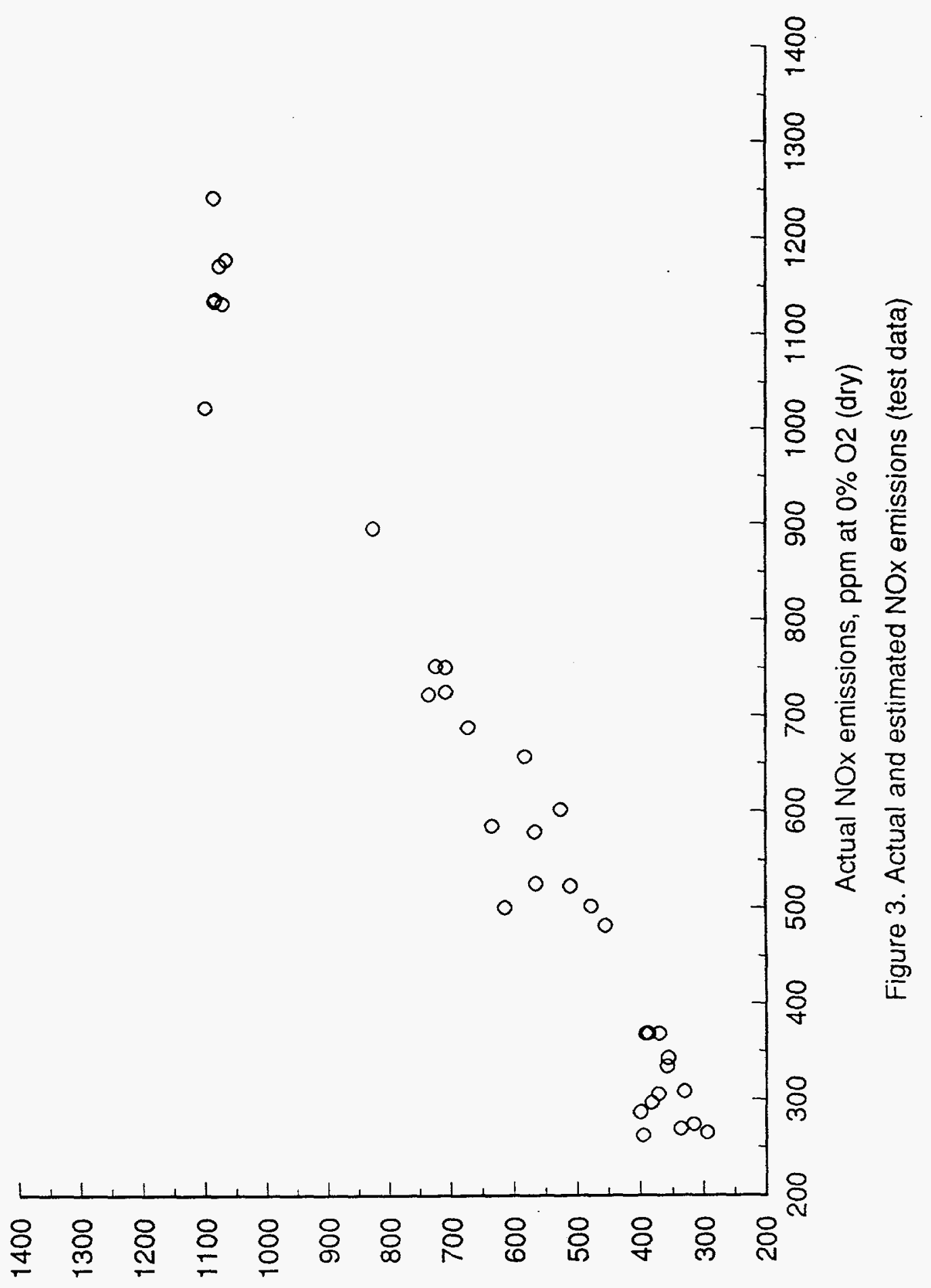

(রup) $20 \% 0$ te wdd 'suo!ss!̣ xON pəłeu!!s $\exists$ 


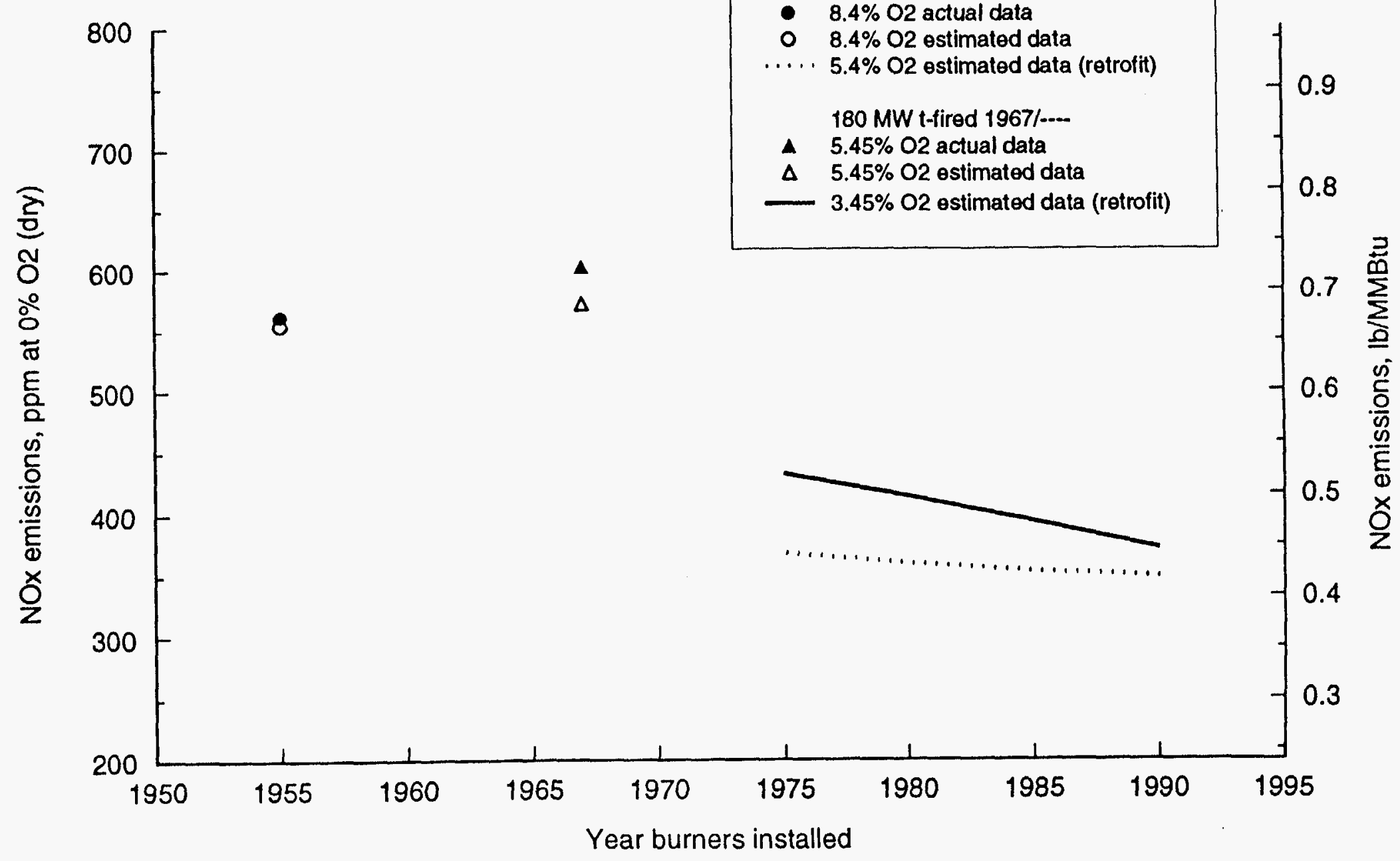

Figure 4. Effect of retrofit burners on NOx emissions 


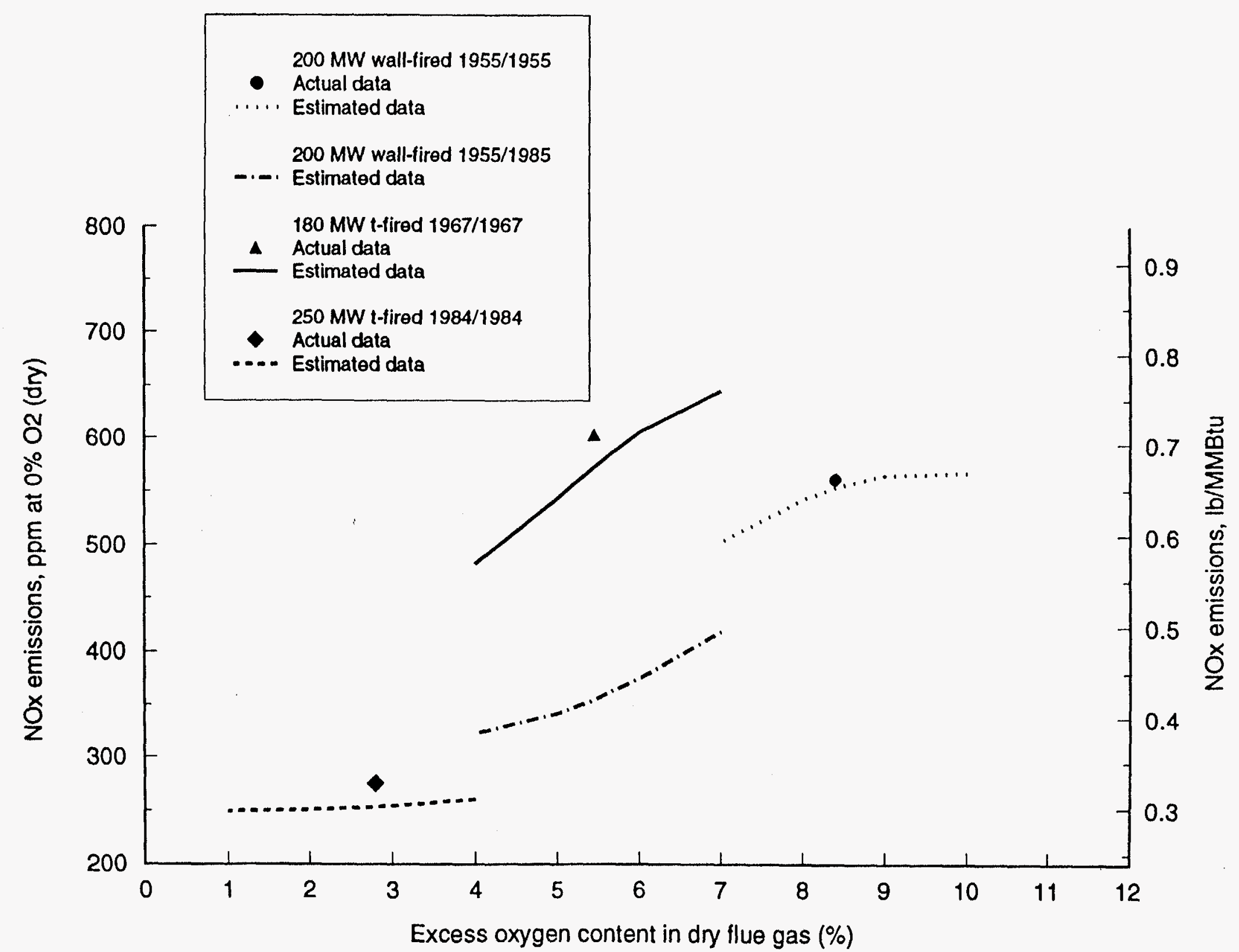

Figure 5. Effect of excess oxygen in flue gas on NOx emissions 


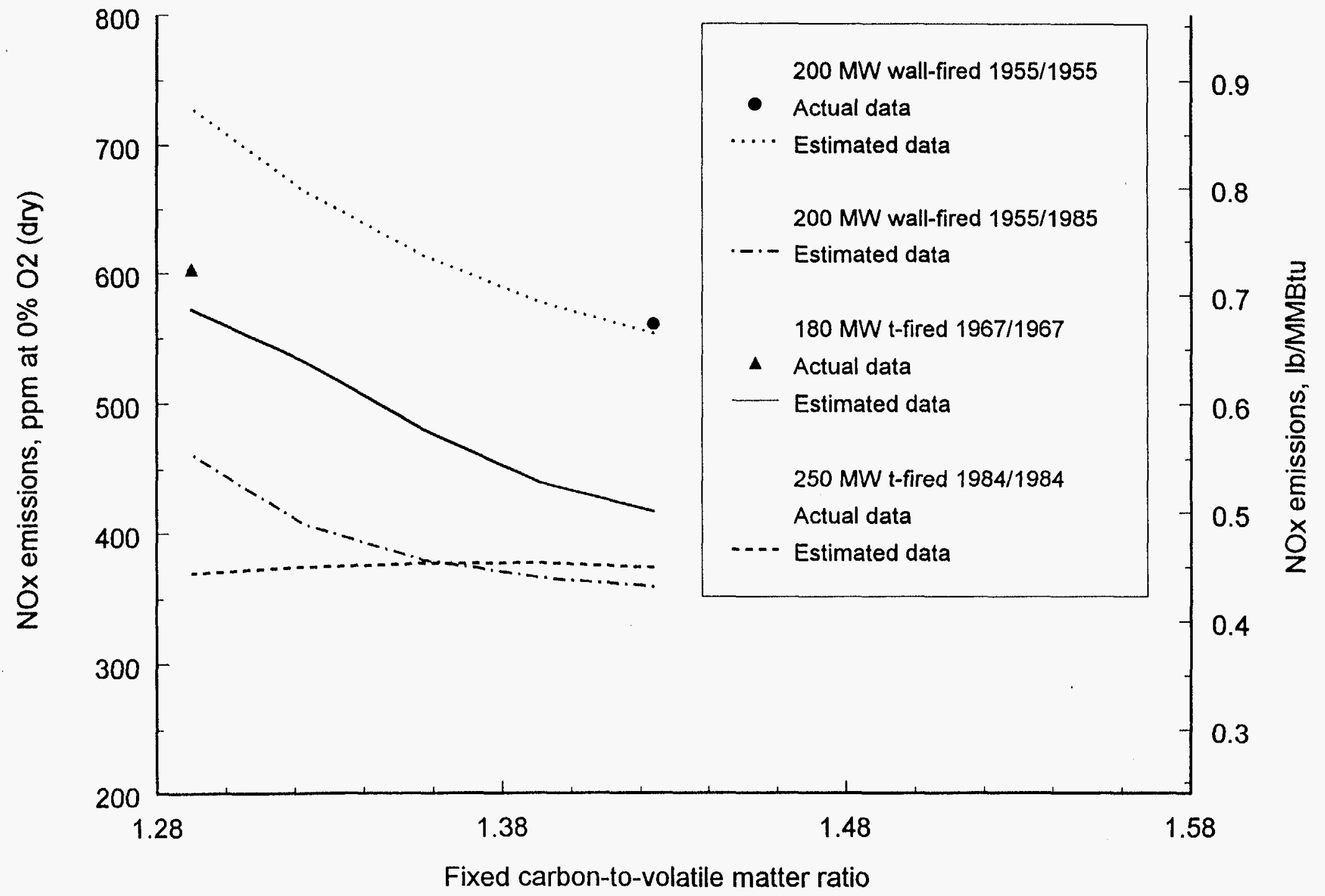

Figure 6. Effect of coal composition on NOx emissions 


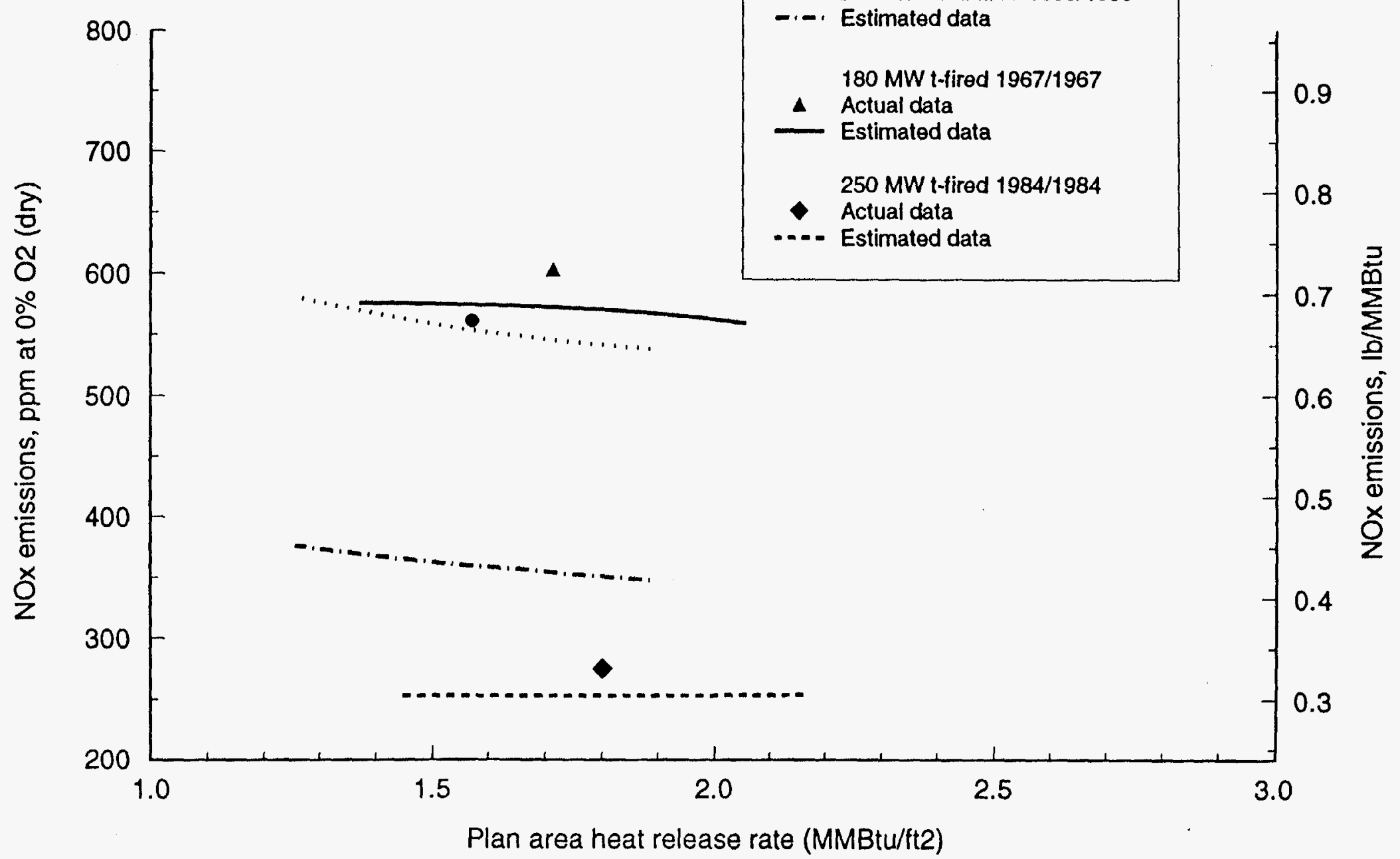

Figure 7. Effect of plan area heat release rate on NOx emissions 


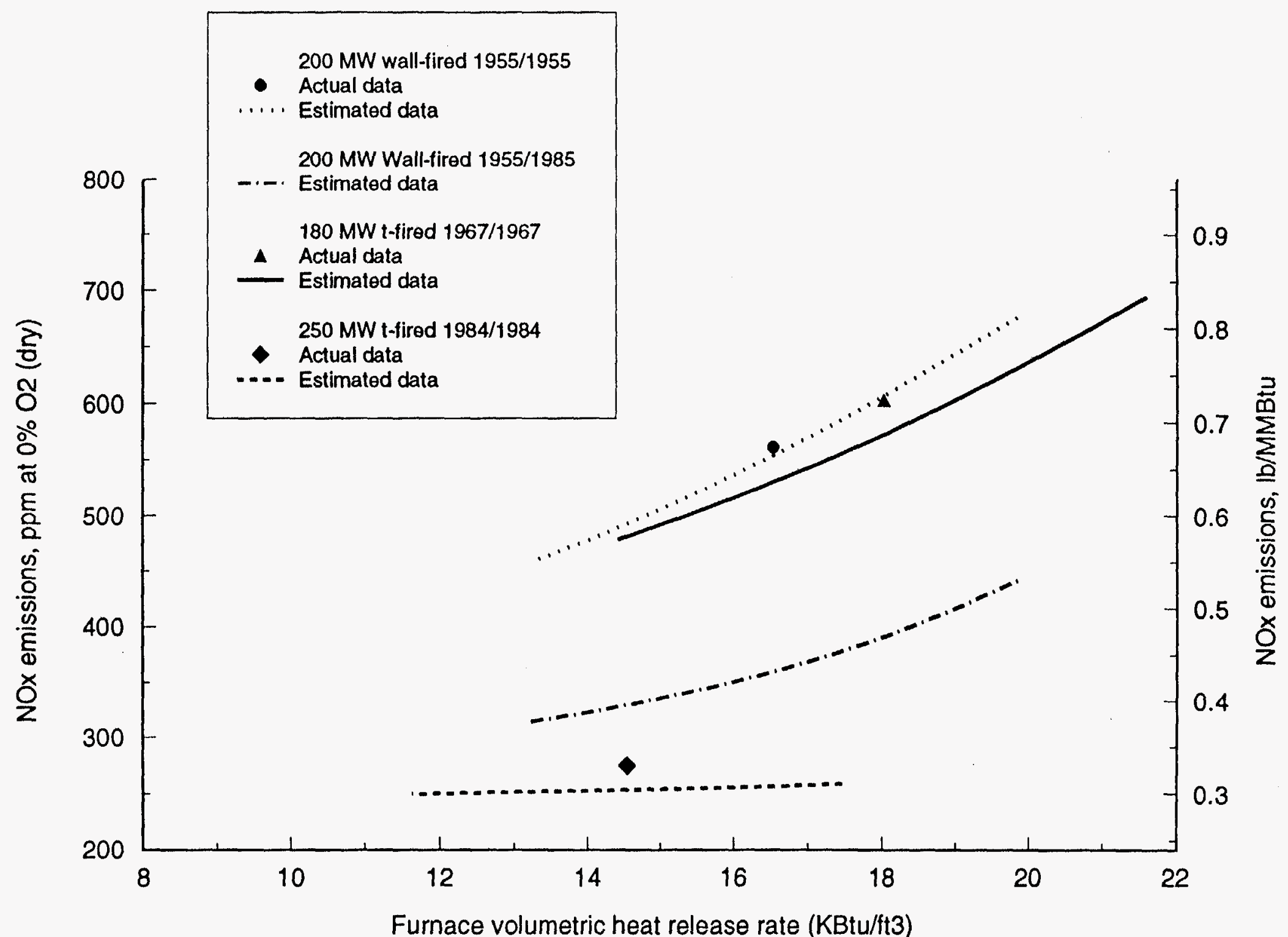

Figure 8. Effect of furnace volumetric heat release rate on NOx emissions 